\title{
Az emberi halántékcsontnak a csecsemő- és kisgyermekkori cochlearis implantáció szempontjából kiemelkedően fontos dimenziói
}

\author{
Klinikoradiológiai vizsgálat \\ Perényi Ádám dr. - Jóri József dr. - Csanády Miklós dr. \\ Bere Zsófia dr. - Rovó László dr. \\ Szegedi Tudományegyetem, Általános Orvostudományi Kar, \\ Fül-Orr-Gégészeti és Fej-Nyaksebészeti Klinika, Szeged
}

\begin{abstract}
Bevezetés: Korai cochlearis implantáció révén a praelingualis (beszéd kialakulása előtti) siketek a halló társadalom teljes értékű tagjaivá válhatnak. A korai diagnosztika széles körben elérhető és megteremti a korai cochlearis implantáció lehetőségét, mégis gyakran a fiatal életkorra hivatkozva későbbre kerül a mútét időpontja.

Célkitüzés: Célunk volt, hogy meghatározzuk a gyermek- és a felnőtthalántékcsont cochlearis implantáció szempontjából releváns anatómiai paramétereit és különbségeit, valamint ezek hatását a mütéti technikára és a mútét időpontjára. Módszer: Irodalmi kutatómunkával és saját beteganyagunkon felmértük a cochlearis implantátum belső elektronikai egységének és aktív elektródájának beültetése során leginkább releváns méreteket: a halántékcsont nagy felbontású komputertomográfiás képein megmértük a halántékcsont squamájának vastagságát, és meghatároztuk a mastoid üregrendszer dimenzióit és a recessus facialis méreteit.

Eredmények: Felmérésünk alapján gyermekeknél szignifikánsan vékonyabbnak bizonyult a koponyacsont és a lágy rész, fejletlen a mastoid üregrendszer, ugyanakkor nincs szignifikáns különbség a recessus facialis méretében.

Következtetés: Csecsemő- és gyermekkori műtétek alkalmával érdemes modern, vékony implantátumot választani, amelyet nem kell csontágyba süllyeszteni. A kerek ablak kiválóan vizualizálható a csecsemók fejletlen mastoid üregrendszerének feltárása által, ami kevesebb csontmunkát igényel, így gyorsabb és kíméletesebb lehet a mútét. Az alacsony életkor sajátosságai óvatosságra intik a fülsebészt, de nem kell a fontos képletek sérülésének nagyobb kockázatától tartania.

Orv Hetil. 2019; 160(24): 936-943.
\end{abstract}

Kulcsszavak: siketség, cochlearis implantátum, bilaterális cochlearis implantáció, minimálisan invazív sebészet, halántékcsont méretei, recessus facialis

\section{Dimensions of the human temporal bone that are relevant to cochlear implantation surgery in infants and toddlers}

\section{A clinical-radiological study}

Introduction: Early cochlear implantation enables prelingual deaf individuals to become full members of the hearing society. Although early diagnostics are widely accessible and enable early rehabilitation, implant surgery often may be delayed due to a candidate's young age.

Aim: The authors' objectives were to determine the anatomical parameters of the pediatric and adult temporal bone that are relevant to cochlear implantation and to ascertain the differences between them in order to assess whether the anatomical differences could influence the surgical technique and the timing of surgery.

Method: Along with a survey of the literature, findings from the authors own cochlear implantees were assessed with respect to the most relevant dimensions of the internal electronic package, including the stimulating electrode of the cochlear implant, by measuring the squama of the temporal bone, the mastoid cavity and the facial recess on high resolution computed tomographic images. 
Results: The skull and the overlying soft tissues proved to be thinner and the mastoid cavity was less developed in children than in adults, while no significant changes were noted in the size of the facial recess.

Conclusions: It is recommended to choose modern, thin implants that do not require sinking the implant package into a bone bed. Less bone work in infants and children enables excellent visualization of the round window through the underdeveloped mastoid cavity, which makes the procedure less time-consuming and minimally invasive. Indeed, a young age should alert ear surgeons to be cautious, but no higher risk of injury to important structures is predicted for young subjects than those that might occur in adults.

Keywords: deafness, cochlear implant, bilateral cochlear implantation, minimal invasive surgery, measurements on temporal bone, facial recess

Perényi Á, Jóri J, Csanády M, Bere Zs, Rovó L. [Dimensions of the human temporal bone that are relevant to cochlear implantation surgery in infants and toddlers. A clinical-radiological study]. Orv Hetil. 2019; 160(24): 936-943.

(Beérkezett: 2018. december 13.; elfogadva: 2019. január 26.)

\section{Rövidítések}

ASSR $=$ (auditory steady-state response) auditoros steady-state válasz; BERA = (brainstem evoked response audiometry) agytörzsi kiváltott válasz audiometria; $\mathrm{CT}=($ computed tomography) számítógépes tomográfia; DPOAE $=($ distortion product otoacoustic emission) disztorziós kombinációs hangemisszió; SD = standard deviáció; SZTE = Szegedi Tudományegyetem

Siket, illetve súlyosan hallássérült csecsemők és kisgyermekek korai cochlearis implantációval teljesen (re)habilitálhatók: elérhető, hogy elkerüljük a beszédfejlődésükben bekövetkező késést, vagy lehetővé tehetjük az ép halló kortársakhoz való gyors felzárkózást [1, 2]. Megfelelő hallás és beszédmegértés hiányában azonban törvényszerúen súlyos halláscsökkenésük, siketségük miatt beszéddel történő kommunikációra képtelenné válnak. A korai eredményes rehabilitáció alapja az a megfigyelés, hogy a hallással kapcsolatos effektoros szinaptikus kapcsolatok és neuralis projekciók hálózata (ún. connectoma) kb. 1,5-2 éves életkorra kialakul [2]. Az újszülöttek általános objektív hallásszürése - amely hazánkban 2015 szeptemberétől kötelező [3] - felgyorsította a diagnosztikát, így korán kiszűrhetők a hallássérültek. Az ezt követő, nagy specificitású és szenzitivitású objektív audiológiai vizsgálatok (ASSR, DPOAE és BERA) biztosítják a pontos diagnózist. Súlyos fokú halláscsökkenés és anacusis esetén - amikor jól beállított, nagy teljesítményű hallókészülékkel sem érhető el megfelelő beszédfejlődés cochlearis implantátum beültetése lehet indokolt [4], amit Magyarországon négy egyetemi klinikai központban (Budapesten, Debrecenben, Pécsen és Szegeden) végzünk. Képalkotó vizsgálatok (a halántékcsont nagy felbontású komputertomográfos vizsgálata vagy 'conebeam' [kúpsugaras] komputertomográfia és az ún. belsőfül-protokoll szerint elvégzett mágneses rezonanciás képalkotó vizsgálatok) segítségével állapítjuk meg, hogy az adott páciens anatómiai statusa lehetóvé teszi-e a beavatkozás elvégzését $[5,6]$. Akár 6 hónapos korra befejeződhet a diagnosztikai sor [7], mégis későbbi időpont- ra kerülhet a cochlearis implantátum beültetése, aminek oka az alacsony életkor miatt felmerülő általános aneszteziológiai aggályokban (a vérveszteség mértéke, kihűlés, a túlhevülés lehetősége, a hosszú mütéti idő, rejtett betegségek) [8], valamint egyes fülsebészek abbéli aggodalmában keresendő, hogy a cochlearis implantáció bonyolultabb múvelet lehet a gyermekpopulációban a felnőtteken végzett beavatkozáshoz képest. Alig találunk azonban olyan adatot a szakirodalomban, amely ez utóbbi feltevést egyértelmüen alátámasztaná [9].

Mütéttechnikailag a cochlearis implantáció három fó szakaszra tagolható:

1. a processzor koponyacsontra illesztése és rögzítése;

2. a stimuláló elektróda eljuttatása a mastoid sejtrendszertől a dobüregbe (mastoidectomia és tympanotomia posterior);

3. a stimuláló elektróda bevezetése a kerek ablak membránján keresztül vagy a cochlea falának megnyitásával (cochleostomán keresztül) a cochlea scala tympani járatába.

Tapasztalatunk szerint az általunk is módosított mútéti technikával, a modern, vékony implantátumok alkalmazásával a mútét időtartama lényegesen lerövidíthető [10].

A fenti korcsoportban igen vékony a koponyacsont és az azt borító lágy rész is [11]. A mastoid sejtrendszer még fejletlen, emiatt a sinus sigmoideus és az arcideg felületesebben helyezkedik el. A leginkább elfogadott módszerrel, a fülsebészeti fúróval végzett részleges mastoidectomiát követő tympanotomia posterior révén nyitjuk meg a dobüreget [6]. A tympanotomia posterior során a recessus facialisban - az incus rövid nyúlványa, a nervus facialis mastoidalis szakasza és a chorda tympani által határolt háromszögben - járatot készítünk a stimuláló elektródának, és biztosítjuk a rálátást a scala tympaniba juttatásának helyére, amely a kerek ablak vagy a csiga bazális kanyarulatán készített cochleostoma lehet (1. ábra).

Ez a mútéti lépés a struktúrák közelsége miatt az arcideg és a chorda tympani sérülésének veszélyét hordozza 


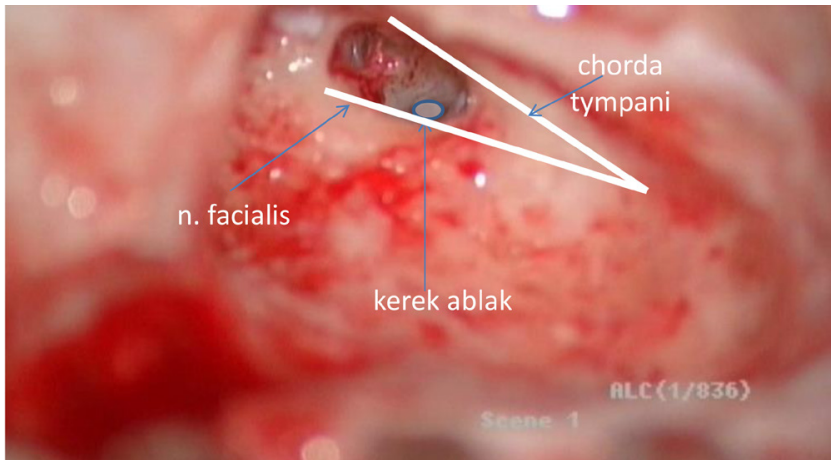

1. ábra

A nervus facialis és a chorda tympani által bezárt szög szárai álta határolt recessus facialis és a benne fúróval készített posterior tympanotomia mikroszkópos mútéti képe. Minimálisan invazív mútét során a kerek ablakon keresztül történik a stimuláló elektróda bevezetése a cochleába

magában. A csecsemők és a kisgyermekek fejkörfogata kisebb a felnőttekénél [12], így logikus arra gondolnunk, hogy a recessus facialis és a dobüreg is kisebb, ezáltal a felnőttkorinál még nagyobb az idegi struktúrák sérülésének veszélye.

Munkánk során megvizsgáltuk, hogy az l év körüli korosztály anatómiai sajátosságai - a halántékcsontnak a cochlearis implantáció szempontjából releváns anatómiai méretei - valóban nehezítik-e a mütét elvégzését, és emiatt indokolt-e a mütét későbbi időpontra halasztása.

\section{Módszer}

Áttekintettük a koponyacsont vastagságára és a recessus facialis méreteire vonatkozó irodalmi adatokat.

Méréseket végeztünk saját beteganyagunkon a mastoid üregrendszer és a recessus facialis méretbeli eltéréseinek felmérésére. Összesen 6 olyan távolságot határoztunk meg, amellyel definiálható a mastoid üregrendszer és a posterior tympanotomia térfogata a halántékcsont vizsgálatára kidolgozott protokollal készített komputertomográfiás (CT) felvételeken:

Dl: incus rövid nyúlványa-tegmen mastoideum (coronalis metszetben, a dobhártya síkjával párhuzamos síkban az incus rövid nyújtványának végpontja és a tegmen mastoideum távolsága);

D2: planum mastoideum-nervus facialis (coronalis metszetben a planum mastoideum és a nervus facialis dobüregi és mastoidealis határának távolsága);

D3: tegmen mastoideum-mastoid csúcs (sagittalis metszetben a mastoid csúcs és a tegmen tympani távolsága);

D4: nervus facialis-rostos dobgyưrü;

D5: kerek ablak-rostos dobgyưrü;

D6: kerek ablak-nervus facialis.

Adatbázisunkból kigyújtöttük a cochlearis implantációt megelőző rutinkivizsgálás részeként a halántékcsontról 2015. január 1. és 2018. augusztus 31. között a Szent-Györgyi Albert Klinikai Központban készített vé- kony szeletes CT-vizsgálatokat. Kizártuk a vizsgálatból azokat az eseteket, amelyekben a csontos labyrinthus fejlődési rendellenességét vagy korábbi mútét jeleit (például mastoidectomia, tympanoplastica) észleltük. A 10 legfiatalabb gyermekről készült vizsgálatokat (átlagéletkor: $1,25 \pm 0,31$ év) és a randomizált módon 10 felnőttről (átlagéletkor: 55,82 \pm 16,93 év) készített sorozatot elemeztük. A méréseket végző személy radiológiai szakképzésben részt vevő fül-orr-gégész szakorvos. A vizsgálatunkba bevont betegeink közül 9 beteg esetében LightSpeed 64 típusú (General Electric, Boston, MA, Amerikai Egyesült Államok) és 11 beteg esetében Brilliance iCT 256 (Philips, Amszterdam, Hollandia) típusú készülékkel történt nagy felbontású CT-vizsgálat (szeletvastagság: 0,625 mm és 0,4 mm). A készülékek különbözősége nem befolyásolja méréseink eredményét a vizsgálati paraméterek jó egyezősége miatt. A távolságméréseket Slicer 4.2 szoftverrel, multiparametrikus nézetben végeztük a vizsgálati alanyok mindkét oldalán. A statisztikai értékelést a Mann-Whitney Sum Rank-próbával végeztük.

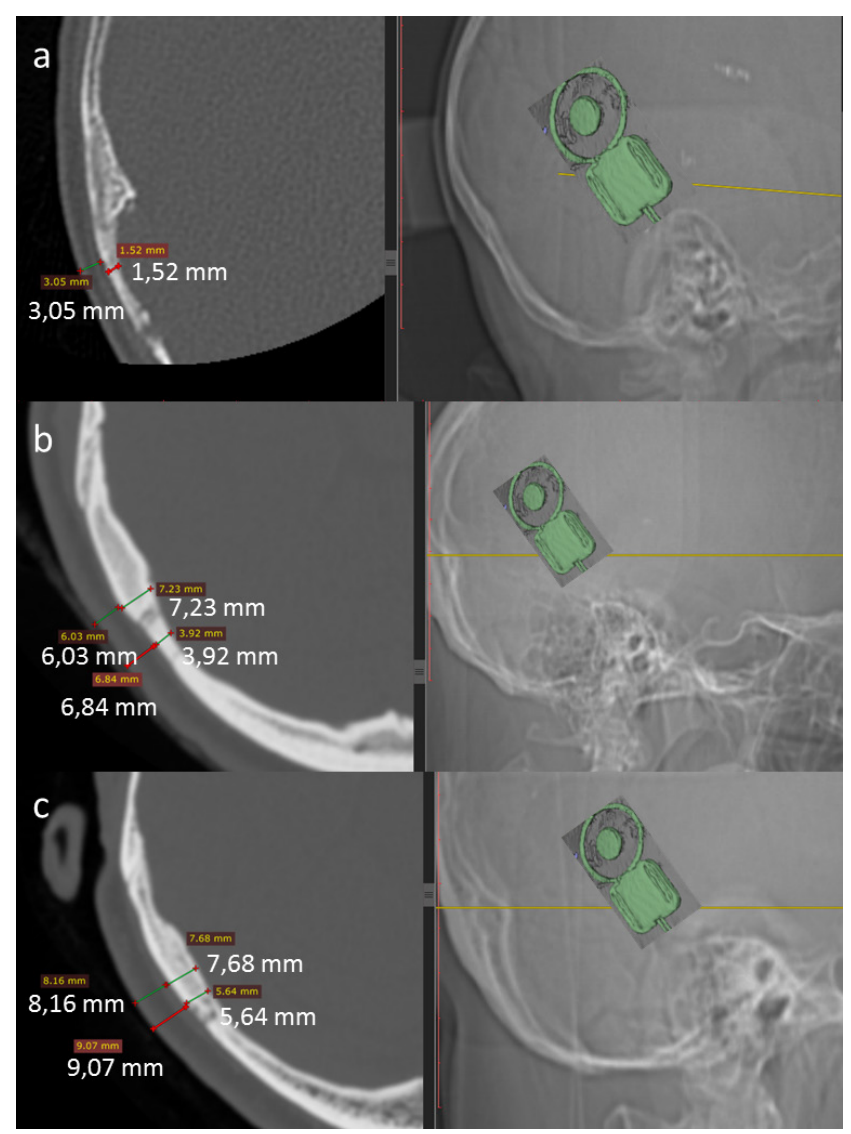

2. ábra Gyermekek és felnőttek koponyacsontjának és lágy részeinek vastagsága a cochlearis implantátum belső egységének helyén [a) 12 hónapos gyermek, b) 7 éves gyermek, c) 75 éves felnőtt]. Bal oldalon csontablakos, axiális síkú CT-szeletek, jobb oldalon topogramokra vetítve egy cochlearis implantátum hozzávetőlegesen méretarányos belső processzora látható. A mérések és a cochlearis implantátum rekonstrukciós képe RadiAnt DICOM Viewer 4.6.5 szoftverrel készült 


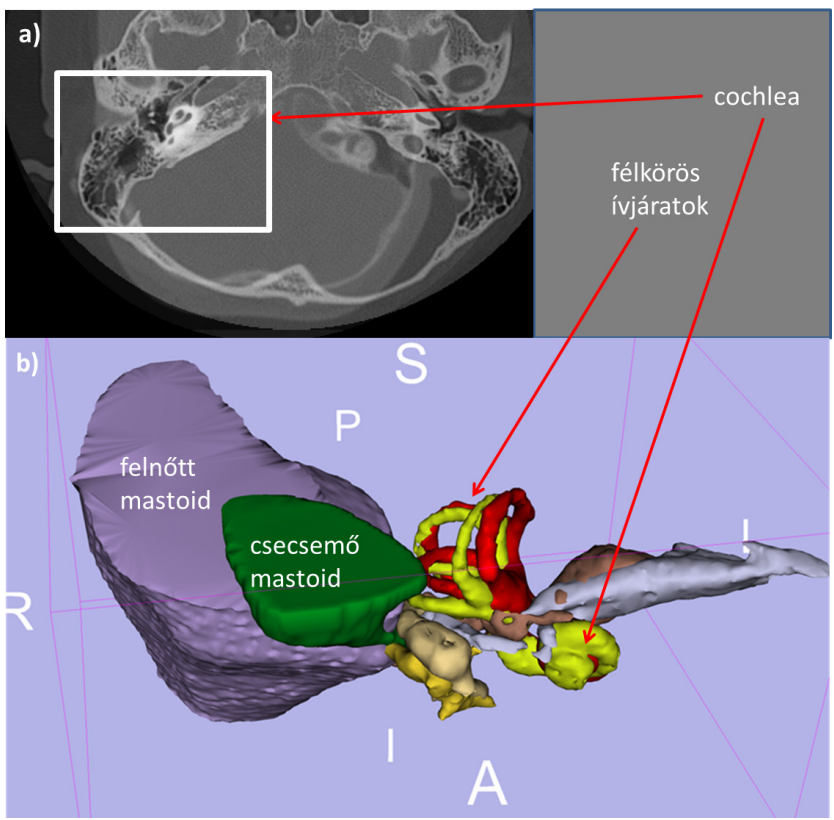

3. ábra

1 éves csecsemő és 50 éves felnőtt halántékcsontjának összehasonlítása szemléltető ábrán. a) A cochlea bazális kanyarulatán áthaladó, axiális síkú CT-szeletek egymásra vetítve. b) 3D Slicer 4.2-vel készített 3D-rekonstrukciók egymásra vetítve. A belsó fülek méretei megegyeznek, lényeges különbséget a mastoid rendszer volumenében találunk

Cochlearis implantáltjaink, illetve törvényes képviselőik előzetesen beleegyeztek klinikai adataik tudományos célból, anonim módon történő felhasználásába.

\section{Eredmények}

Nagy esetszámra vonatkozó irodalmi adatok alapján megállapítható, hogy a gyermekek koponyacsontja szignifikánsan vékonyabb, mint a felnótteké $(3,39 \pm 1,05 \mathrm{SD}$ $\mathrm{mm}$ versus $6,33 \pm 0,64 \mathrm{SD} \mathrm{mm}$ ) [11]. Ezek az értékek használhatók a cochlearis implantátumok belső procesz- szorának helyén is, ezért azokat alapul véve a 2. ábrán szemléltetjük a méretbeli eltéréseket.

A szakirodalmi adatok szerint a recessus facialis és a belső fül méretei már a születéskor megegyeznek a felnőttkori méretekkel [13-15].

A halántékcsont méreteit illetően a szakirodalmi adatok szerint a hártyás labyrinthus a 16-20. intrauterin hétre eléri a felnőttkori méreteket [16], és annak ellenére, hogy a halántékcsont pars squamosája, a dobüreg és a mastoid üreg növekszik, a csontos labyrinthus mérete nem változik az életkor elörehaladtával [13].

Saját implantáltjaink példáján keresztül is megalapozottnak találjuk a fenti állítást, és a 3. ábrán szemléltetjük.

Találtunk olyan irodalmi adatot, mely szerint elképzelhető, hogy statisztikailag szignifikánsan változik a cochlea bazális kanyarulatának sziklacsonton belüli orientációja a korai életszakaszban (2 éves korig), és a 2 éves életkort követően nem változik ez a tényező [17].

A mastoid üregrendszer méretbeli változásának megítélése céljából a saját beteganyagunkon végzett méréseink eredményét a $4 / a-c$ ábrákon mutatjuk be.

Az incus rövid nyúlványa és a tegmen mastoideum távolsága (Dl) felnőtteknél 5,0 $\pm 1,5 \mathrm{~mm}$, míg gyermekeknél $6,5 \pm 1,9 \mathrm{~mm}(\mathrm{p}=0,014)$, tehát gyermekeknél szignifikánsan nagyobb (4/a ábra). A planum mastoideum és az arcideg távolsága (D2) gyermekeknél 13,2 \pm 1,9 mm, míg felnótteknél 24,3 $\pm 3,5 \mathrm{~mm}(\mathrm{p}<0,001)$, tehát felnőtteknél szignifikánsan nagyobb (4/b ábra). A tegmen mastoideum és a mastoid csúcs távolsága (D3) gyermekeknél 17,8 $\pm 2,4 \mathrm{~mm}$, míg felnőtteknél 35,9 \pm $5,6 \mathrm{~mm}(\mathrm{p}<0,001)$, tehát felnőtteknél szignifikánsan nagyobb (4/c ábra).

Ugyanazon beteganyagunkon a recessus facialis méretének és a kerek ablak mélységi viszonyainak változására vonatkozó méréseink eredményét az $5 / a-c$ ábrákon ábrázoljuk.

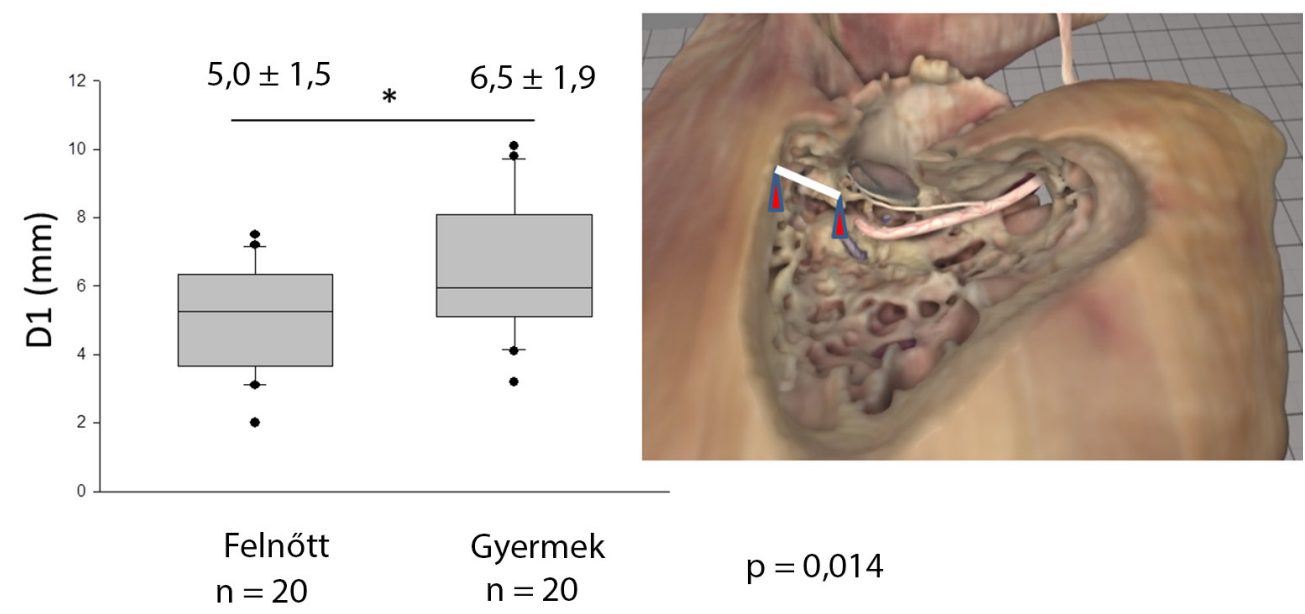

4/a ábra $\quad$ Az incus rövid nyúlványa és a tegmen mastoideum távolsága gyermekeknél nagyobb, mint felnőtteknél. Bal oldalon a diagramon a mérések átlagát tüntettük fel, jobb oldalon virtuális háromdimenziós ábrán (3D Slicer 4.2, Virtual Ear Simulator) a vizsgált távolságot (D1) fehér vonallal jelöltük 


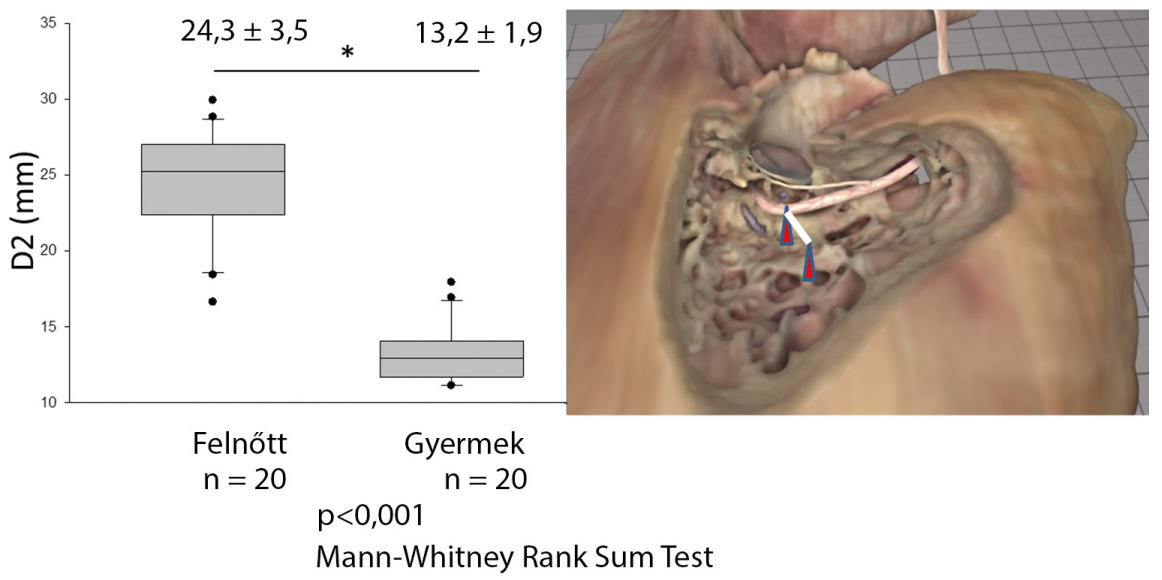

$4 / b$ ábra

A planum mastoideum és az arcideg közötti távolság gyermekeknél szignifikánsan rövidebb, mint felnőtteknél. Bal oldalon a diagramon a mérések átlagát tüntettük fel, jobb oldalon virtuális háromdimenziós ábrán (3D Slicer 4.2, Virtual Ear Simulator) a vizsgált távolságot (D2) fehér vonallal jelöltük

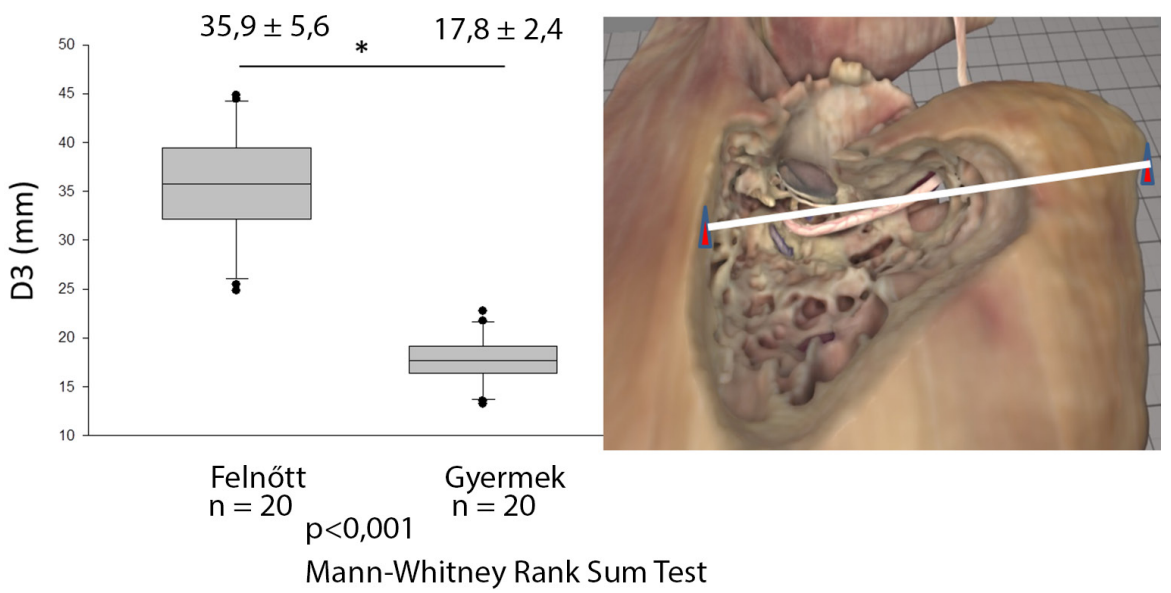

4/c ábra $\quad$ A tegmen mastoideum és a mastoid csúcs közötti távolság gyermekeknél szignifikánsan rövidebb, mint felnőtteknél. Bal oldalon a diagramon a mérések átlagát tüntettük fel, jobb oldalon virtuális háromdimenziós ábrán (3D Slicer 4.2, Virtual Ear Simulator) a vizsgált távolságot (D3) fehér vonallal jelöltük

A nervus facialis és a rostos dobgyürü távolsága (D4) felnőttekben $5,4 \pm 0,7 \mathrm{~mm}$ és gyermekekben 5,2 $\pm 0,7$ $\mathrm{mm}(5 / a$ ábra $)$. A kerek ablak és a rostos dobgyứü távolsága (D5) felnőttekben 6,7 $\pm 0,6 \mathrm{~mm}$ és gyermekekben $6,9 \pm 0,8 \mathrm{~mm}(5 / b$ ábra). A kerek ablak és a nervus facialis távolsága (D6) felnőttekben $5,2 \pm 0,1 \mathrm{~mm}$ és gyermekekben $6,6 \pm 0,7 \mathrm{~mm}$ (5/c ábra). Nem tapasztaltunk szignifikáns különbséget a D4-D6 távolságokban a felnőttek és a gyermekek között.

\section{Megbeszélés}

A gyermekek koponyacsontja és az azt borító lágy részek lényegesen vékonyabbak a felnőttekénél [11]. A korábbi típusú implantátumok belső elektronikai egysége jelentősen vastagabb volt a modern, vékony elektronikai kapszulával rendelkező implantátumokénál [10], ezért mindenképpen be kellett süllyeszteni őket a koponyacsontba, ami a koponya integritását károsítva meggyengítette azt. A klasszikus, széles körben alkalmazott mütéti technika $[6,18]$ számos, akár súlyos szövődmény (agyinfarktus

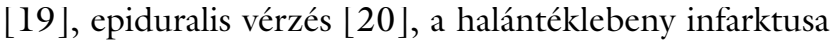
és a sinus sigmoideus trombózisa [21], subduralis vérzés, agygerincvelői folyadék szivárgása [22], lágy részek elhalása) veszélyét is hordozza. A vékony profilú implantátumok megjelenése megteremtette a "subperiostealis pocket” [23] és a „szoros subperiostealis pocket” [24] technika lehetőségét - mely utóbbit a SZTE Fül-OrrGégészeti Klinikáján a legtöbb esetben alkalmazunk. Nemzetközi multicentrikus tanulmányunk eredményéből arra következtettünk, hogy a vékony implantátumokat rövid bőrmetszést követően kis feltárásból, akár csontágy készítése nélkül, a lágy részek integritásának megbontása, ezáltal meggyengítése nélkül ültethetjük be, és nincs szükség rögzítő varratokra [10]. Ezzel a technikával - amellett, hogy a beavatkozás minimálisan invazívvá válik - a műtéti időtartam is jelentősen lerövidíthető.

$\mathrm{Az}$ antrum craniocaudalis méretét jellemezhetjük az incus rövid nyúlványa és a tegmen mastoideum távolságával (Dl). A mastoid üregrendszer laterolateralis méretét (mélységét) a planum mastoideum és az arcideg tá- 


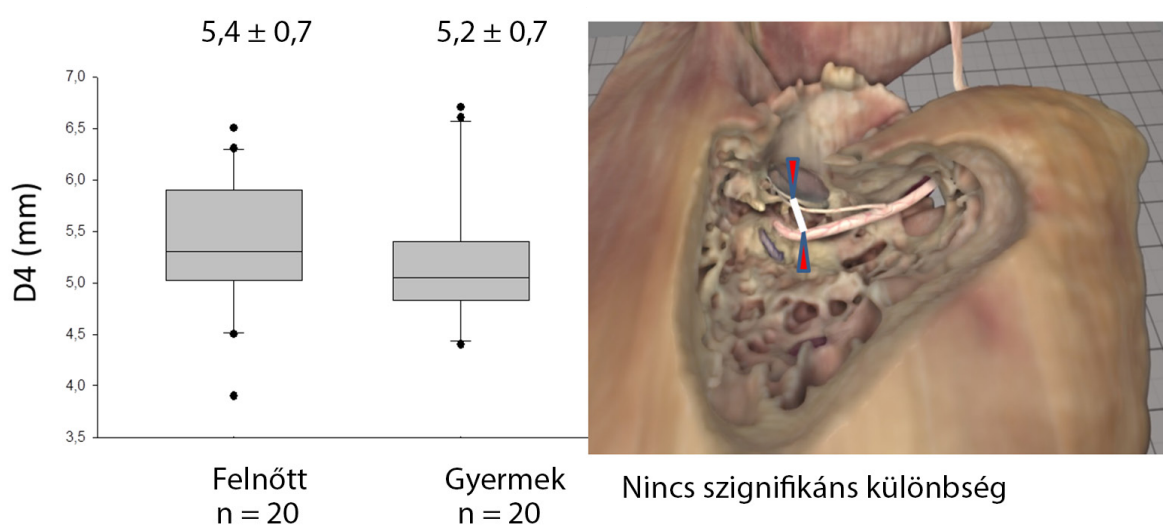

5/a ábra Az arcideg és a rostos dobgyưrú távolságát vizsgálva nincs szignifikáns különbség gyermekek és felnőttek között. Bal oldalon a diagramon a mérések átlagát tüntettük fel, jobb oldalon virtuális háromdimenziós ábrán (3D Slicer 4.2, Virtual Ear Simulator) a vizsgált távolságot (D4) fehér vonallal jelöltük
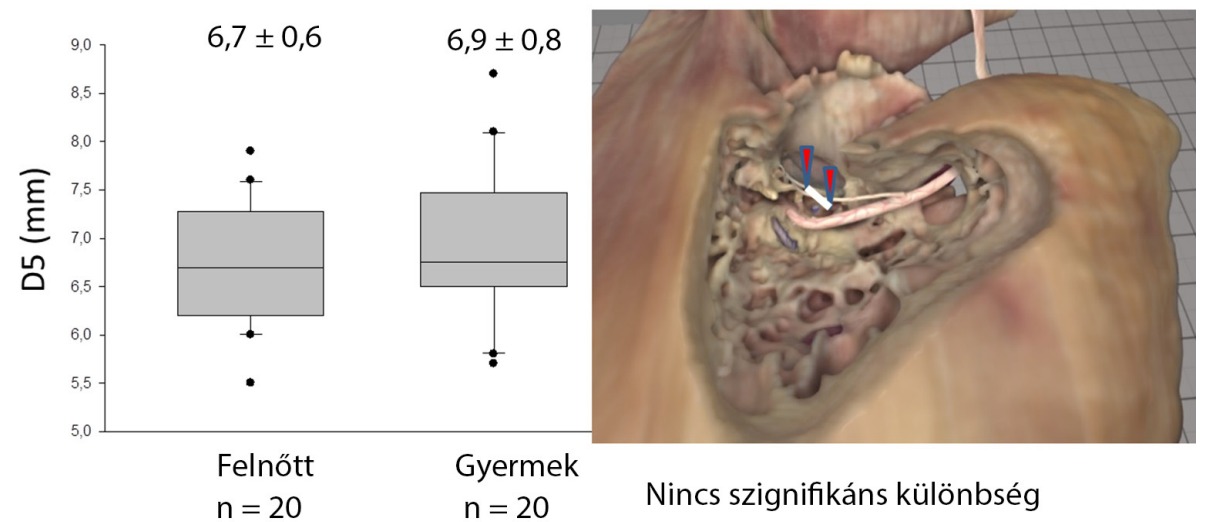

5/b ábra $\quad$ A kerek ablak és a rostos dobgyürű távolságát vizsgálva nincs szignifikáns különbség gyermekek és felnőttek között. Bal oldalon a diagramon a mérések átlagát tüntettük fel, jobb oldalon virtuális háromdimenziós ábrán (3D Slicer 4.2, Virtual Ear Simulator) a vizsgált távolságot (D5) fehér vonallal jelöltük
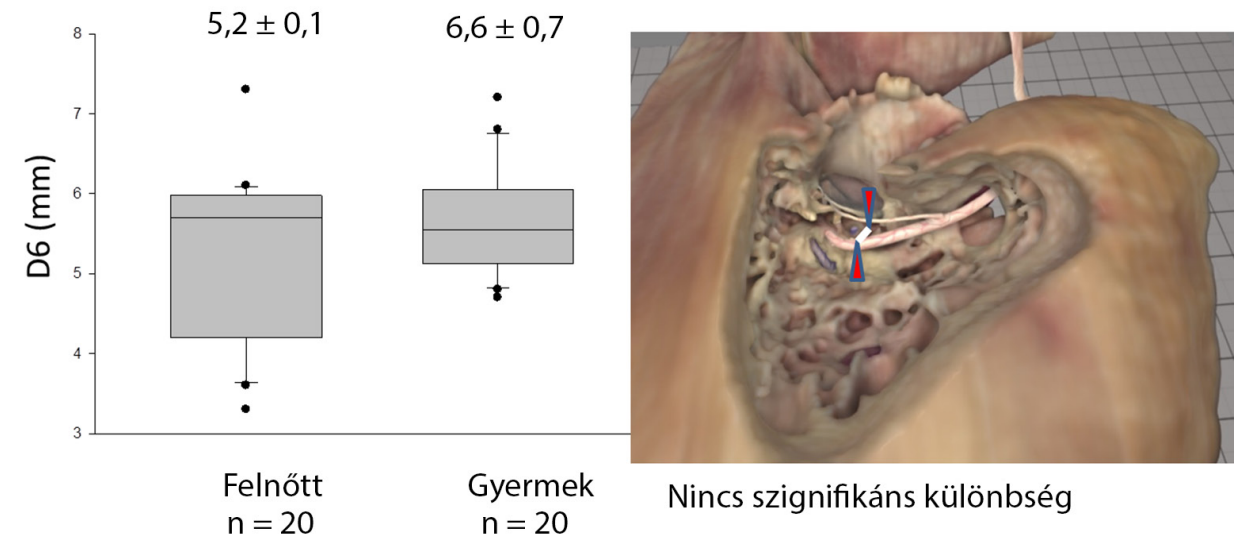

$5 / c$ ábra

A kerek ablak és az arcideg távolságát vizsgálva nincs szignifikáns különbség gyermekek és felnőttek között. Bal oldalon a diagramon a mérések átlagát tüntettük fel, jobb oldalon virtuális háromdimenziós ábrán (3D Slicer 4.2, Virtual Ear Simulator) a vizsgált távolságot (D6) fehér vonallal jelöltük

volsága (D2), craniocaudalis kiterjedését a tegmen mastoideum és a mastoid csúcs távolsága (D3) adja meg. A D1 : D3 arány - amely az antrum és a mastoid üreg arányát adja meg - a felnőtteknél 0,14 , a gyermekeknél 0,37 , miközben a Dl a gyermekeknél a felnőttekhez képest nagyobb és a D3 a gyermekeknél a felnőttekhez ké- pest szignifikánsan kisebb volt. Megjegyezzük, hogy az újszülötteknek még nincs pneumatizált mastoidalis sejtrendszerük, csak az antrum mastoideum van jelen, mely légtartó vagy embrionális kötőszövettel van kitöltve, és belőle kiindulva fejlődnek és 1 éves kor körül jelennek meg a légtartó mastoid sejtek [25]. 
Sebészi könnyebbséget jelent és gyorsítja a mütétet, hogy gyermekek esetében kevesebb csontot kell eltávolítani, ugyanakkor - mivel az arcideg kevésbé mélyen fut óvatosabb munkával kell kialakítani a sekélyebb mastoidectomiás üreget. Óvatosságra int az az eredményünk is, hogy az antrum mérete a teljes mastoid üreg craniocaudalis kiterjedéséhez viszonyítva relatíve nagy, ami miatt könnyen „eltévedhet” és okozhatja az arcideg sérülését a gyermekfülmütétekben tapasztalatlan sebész. Megjegyezzük, hogy a gyermekkori fülmütétek száma jelentősen csökkent, és a fülsebészeti és cochlearis implantációs kurzusokon is felnőtt specimeneken gyakorolnak a résztvevők. Biztonságos megoldást kínál, ha a tegmen mastoideum mentén haladva keressük fel az antrumot, és így hozzuk látótérbe az incus rövid nyúlványát, amely rámutat az arcidegre. Ezt követően biztonságosan előkészíthetjük a területet a dobüreg megnyitására. Arcidegmonitor rutinszerű alkalmazásával tovább fokozhatjuk a biztonságot.

A nemzetközi szakirodalomban fellelt kadáver- és képalkotó vizsgálatok eredménye - melyek szerint míg a koponya méretei nőnek a születéstől kezdve gyermekkorban, addig a belső fül és a recessus facialis méretei már a születéskor megegyeznek a felnőttkori méretekkel [1315] - megfelel klinikai tapasztalatainknak és saját beteganyagunkon végzett méréseink eredményének (4. és 5 . ábra). Ez azt jelenti, hogy a dobüreg legelfogadottabb megnyitási módszerében, az ún. tympanotomia posteriorban nincs érdemi különbség. További klinikai tapasztalatunk, hogy gyermeken kevésbé scleroticus a tympanotomia posterior során elfúrandó csontállomány, ami megkönnyíti a fúrást és az idegi struktúrák csontállományon belüli elkülönítését.

\section{Következtetés}

A cochlearis implantáció mütéti technikája nem jelent szükségszerüen nagyobb kockázatot az alacsony életkor anatómiai sajátosságai miatt. A mastoid üreg fejletlensége csecsemő- és kisgyermekkorban megkönnyíti a kerek ablak vizualizálását, és a koponyacsonton végzett kevesebb csontmunka által még kisebb traumával végezhető el a mútét. Vizsgálatunkból arra következtetünk, hogy az 1 év körüli korosztály anatómiai sajátosságai - a halántékcsontnak a cochlearis implantáció szempontjából releváns anatómiai méretei - nem nehezítik meg a mútét elvégzését, és nem indokolják a hallásrehabilitációs mütét halogatását.

Anyagi támogatás: A közlemény megírása, illetve a kapcsolódó kutatómunka anyagi támogatásban nem részesült.

Szerzői munkamegosztás: P. Á.: A CT-felvételeken végzett mérések, a protokoll kidolgozása, a vizsgálat lefolytatása, a kézirat megszövegezése, a CT-felvételek 3D-re- konstrukciójának elkészítése. J. J., R. L.: A protokoll kidolgozása, mútétek végzése, a kézirat megszövegezése. Cs. M.: A kézirat megszövegezése. B. Zs.: Az eredmények statisztikai elemzése. A cikk végleges változatát valamennyi szerző elolvasta és jóváhagyta.

Érdekeltségek: A szerzőknek nincsenek érdekeltségeik.

\section{Köszönetnyilvánítás}

A szerzők köszönetet mondanak a Szegedi Tudományegyetem SzentGyörgyi Albert Klinikai Központ Radiológiai Klinikájának és az Affidea Diagnosztika Kft.-nek a kiváló minőségű komputertomográfos vizsgálatok elvégzéséért. Köszönet illeti $d r$. Nagy Attilát a Slicer 4.2 szoftver kezelésének elsajátításában, Szamosközi Alicét és Perényi-Csáthi Évát a kézirat tartalmi és nyelvhelyességi ellenőrzésében nyújtott segítségért.

\section{Irodalom}

[1] Hehar SS, Nikolopoulos TP, Gibbin KP, et al. Surgery and functional outcomes in deaf children receiving cochlear implants before age 2 years. Arch Otolaryngol Head Neck Surg. 2002; 128: 11-14.

[2] Kral A, Kronenberger WG, Pisoni DB, et al. Neurocognitive factors in sensory restoration of early deafness: a connectome model. Lancet Neurol. 2016; 15: 610-621.

[3] Guidelines of the Ministry of Human Resources for full age-related hearing screening of children aged 0-18 years and for the care and rehabilitation of filtered children. [Az Emberi Erőforrások Minisztériuma szakmai irányelve a 0-18 éves korú gyermekek teljes körű, életkorhoz kötött hallásszűréséről és a kiszürt gyermekek gondozásba, rehabilitációba vételéről. 2015. EüK 9. szám EMMI szakmai irányelv hatályos: 2015. 05. 27től.] Emberi Erőforrások Minisztériuma - Egészségügyért Felelős Államtitkárság, Budapest, 2015. Available from: http:// www.hbcs.hu/uploads/jogszabaly/2203/fajlok/ 0_18_eves_ koru_gyermekek.pdf [accessed: December 12, 2018]. [Hungarian]

[4] Deggouj N, Gersdorff M, Garin P, et al. Today's indications for cochlear implantation. B-ENT 2007; 3: 9-14.

[5] Perényi Á, Bella Zs, Baráth Z, et. al. Role of cone-beam computed tomography in diagnostic otorhinolaryngological imaging. [A cone-beam komputertomográfia alkalmazása a fül-orrgégészeti képalkotásban.] Orv Hetil. 2016; 157: 52-58. [Hungarian]

[6] Lenarz T. Cochlear implant - state of the art. GMS Curr Top Otorhinolaryngol Head Neck Surg. 2017; 16: Doc04. doi: $10.3205 /$ cto000143.

[7] Cunningham RF. Cochlear implants. In: A resource guide for early detection and intervention. NCHAM eBook, Chapter 13, 1-12. National Center for Hearing Assessment and Management, Utah State University, Logan, UT, 2015. Available from: http://www.infanthearing.org/ehdi-ebook/2015_ebook/13Chapter13CochlearImpants2015.pdf [accessed: December 12, 2018].

[8] Basura GJ, Eapen R, Buchman CA. Bilateral cochlear implantation: current concepts, indications, and results. Laryngoscope 2009; 119: 2395-2401.

[9] McRackan TR, Reda FA, Rivas A, et al. Comparison of cochlear implant relevant anatomy in children versus adults. Otol Neurotol. 2012 ; 33: 328-334.

[10] Perenyi A, Toth F, Nagy AA, et al. Early experience on a modern, thin cochlear implant family. A retrospective, international multicenter study. J Med Life 2018; 11: 146-152.

[11] Posta B, Jarabin JA, Perényi Á, et al. Pediatric hearing rehabilitation with the Baha ${ }^{\circledR}$ Attract implant system. [Fiatalkori hallásre- 
habilitáció Baha ${ }^{\circledR}$ Attract implantátumrendszerrel] Orv Hetil. 2017; 158: 304-310. [Hungarian]

[12] Nellhaus G. Head circumference from birth to eighteen years: practical composite international and interracial graphs. Pediatrics 1968; 41: 106-114.

[13] Eby TL, Nadol JB Jr. Postnatal growth of the human temporal bone. Implications for cochlear implants in children. Ann Otol Rhinol Laryngol. 1986; 95: 356-364.

[14] O'Donoghue GM, Jackler RK, Jenkins WM, et al. Cochlear implantation in children: the problem of head growth. Otolaryngol Head Neck Surg. 1986; 94: 78-81.

[15] Dahm MC, Shepherd RK, Clark GM. The postnatal growth of the temporal bone and its implications for cochlear implantation in children. Acta Otolaryngol Suppl. 1993; 505: 1-39.

[16] Bast TH. XXXII Development of the otic capsule: VI. Histological changes and variations in the growing bony capsule of the vestibule and cochlea. Ann Otol Rhinol Laryngol. 1942; 51: 343-357.

[17] Kiran AS, Varghese AM, Irodi A, et al. Radiological evaluation of cochlear orientation and its implications in cochlear implantation. Indian J Otolaryngol Head Neck Surg. 2018; 70: 1-9.

[18] Clark GM, Pyman BC, Balley QR. The surgery for multiple electrode cochlear implantations. J Laryngol Otol. 1979; 93: 215223.

[19] Proops DW, Stoddart RL, Donaldson I. Medical, surgical and audiological complications of the first 100 adult cochlear implant patients in Birmingham. J Laryngol Otol Suppl. 1999; 24: 1417.

[20] Gosepath J, Maurer J, Mann WJ. Epidural hematoma after cochlear implantation in a 2.5 -year-old boy. Otol Neurotol. 2005 ; 26 : 202-204.

[21] Staecker H, Chow H, Nadol JB Jr. Osteomyelitis, lateral sinus thrombosis and temporal lobe infarction caused by infection of a percutaneous cochlear implant. Am J Otol. 1999; 20: 726-728.

[22] Dodson K, Maiberger P, Sismanis A. Intracranial complications of cochlear implantation. Otol Neurotol. 2007; 28: 459-462.

[23] Balkany TJ, Whitley M, Shapira Y, et al. The temporalis pocket technique for cochlear implantation: an anatomic and clinical study. Otol Neurotol. 2009; 30: 903-907.

[24] Jethanamest D, Channer GA, Moss WJ, et al. Cochlear implant fixation using a subperiosteal tight pocket without either suture or bone-recess technique. Laryngoscope 2014; 124: 16741677.

[25] Cheatle AH. The infantile types of mastoid with ninety-six specimens. J Laryngol. 1907; 22: 256.

(Perényi Ádám dr., Szeged, Tisza Lajos krt. 111., 6725 e-mail: perenyi.adam@med.u-szeged.hu)

\section{"Natura artis magistra." (A természet a művészet tanítómestere.)}

A cikk a Creative Commons Attribution 4.0 International License (https://creativecommons.org/licenses/by/4.0/) feltételei szerint publikált Open Access közlemény, melynek szellemében a cikk bármilyen médiumban szabadon felhasználható, megosztható és újraközölhető, feltéve, hogy az eredeti szerző és a közlés helye, illetve a CC License linkje és az esetlegesen végrehajtott módosítások feltüntetésre kerülnek. (SID_1) 